\title{
PENGEMBANGAN FITUR DOWNTIME REPORTING DAN MODUL SUMMARY PADA SISTEM MONITOR DAN PELAPORAN OPERASIONAL MESIN ECRM
}

\author{
Prihatin Oktivasari $^{1}$, Zufar Fathi Suhardi ${ }^{2}$ \\ ${ }^{1,2}$ Teknik Informatika, Jurusan Teknik Informatika dan Komputer \\ Politeknik Negeri Jakarta \\ E-mail: ti2n_oktivasari@yahoo.com
}

\begin{abstract}
ABSTRAK
Dalam meningkatkan monitoring performa harian mesin eCRM (Cash Recycling Machine), diperlukan suatu aplikasi yang dapat memantau mesin secara mendetail. CRM merupakan alat yang berfungsi untuk menyalurkan, menyimpan dan mengatur data-data kegiatan engineer terhadap mesin dari engineer kepada supervisor dan manager sehigga dapat dilakukannya evaluasi kegiatan pada lapangan, banyak digunakan untuk memenuhi kebutuhan konsumen dalam bidang perbankan khususnya Automated Teller Machine (ATM). Pengembangan fitur downtime reporting diperlukan untuk menyimpan data jumlah downtime seluruh mesin di Indonesia, sehingga memudahkan manager dan supervisor dalam memanage mesin dan engineer berdasarkan data peforma mesin di lapangan. Sistem dibangun menggunakan php framework CodeIgniter.dengan prinsip kerja Model-View-Controller sehingga dapat digunakan untuk mengembangkan aplikasi secara efisien dan dinamis serta lebih memudahkan dalam melakukan pemeliharaan aplikasi.
\end{abstract}

Kata Kunci: eCRM, downtime reporting, CodeIgniter

\begin{abstract}
In improving the daily performance monitoring machine ECRM (Cash Recycling Machine), required an application that can monitor the machine in detail. CRM is a tool that serves to distribute, store and manage data activity on the machine engineer from engineer to supervisors and managers can sehigga evaluation of activities in the field, widely used to meet the needs of consumers in the field of banking, especially Automated Teller Machine (ATM). The development of downtime reporting features required to store data on the number of downtime across machines in Indonesia, making it easier for managers and supervisors in managing the machine and engineer based on data Performance machines in the field. $\neg$ Sistem built using php framework Code Igniter.dengan working principles of Model-ViewController so it can be used to develop applications efficiently and dynamically as well as make it easier to perform maintenance applications.
\end{abstract}

Key words: eCRM, downtime reporting, CodeIgniter 


\section{PENDAHULUAN}

Cash Recycling Machine (CRM) merupakan produk dari Hitachi-Omron Terminal Solutions (HOTS) untuk memenuhi kebutuhan konsumen dalam bidang perbankan khususnya Automated Teller Machine (ATM). Aplikasi yang dibuat di dalamnya belum mencakup data performa harian mesin eCRM yang lebih mendetail, sehingga sulit untuk memantau mesin mana yang di anggap bad boy atau mesin yang sering terjadi kendala. Selain itu pada sistem monitor dan pelaporan operasional mesin eCRM seluruh Indonesia sebelumnya terdapat beberapa kekurangan seperti kurang interaktif, kurang efisien, dan data kurang mendetail di saat engineer membuka fitur summary. Berdasarkan permasalahan tersebut, dalam penelitian inimelakukan beberapa pangembangan guna mempernbaiki serta menambah nilai guna aplikasi sebelumnya. Pengembangan yang dibuat yaitu penambahan fitur downtime reporting dan pembaruan User Interface modulsummary. Diharapkan dengan adanya penambahan fitur-fiturtersebut akan membantu pihak-pihak terkait sehingga dapat mengefektifkan dan mengefesiensikan pekerjaan yang dikerjakan, yaitu dengan mengembangkan penampilan informasi performa mesin yang aktif berdasarkan periode, penampilan informasi progress preventive maintenance (PM) per service area di Indonesia, penampilan informasi PM harian per service area di Indonesia, dan penampilan daftar mesin yang belum ter PM.

\section{LANDASAN TEORI}

\section{1. eCRM}

eCRM merupakan kombinasi dari Cash Deposit Machine (CDM) dan Automated Teller Machine (ATM) dalam satu mesin untuk menawarkan fungsi deposit dan dispense. eCRM merupakan mesin yang di produksi HOTS dan pada berapa perusahaan perbankan di Indonesia, mesin ini menggunakan software yang diproduksi oleh PT. IBM Indonesia.

\subsection{PM}

Prihatin Oktivasari: Pengembangan fiture....
PM atau Preventive Maintenance, merupakan kegiatan yang dilakukan oleh engineer Jasa Teknologi Informasi (JTI), terhadap mesin-mesin eCRM IBM-HOST yang aktif di seluruh Indonesia. Kegiatan PM ini dilakukan oleh engineer secara berkala.

\subsection{PHPExcel}

PHPExcel merupakan project yang menyediakan satu paket class untuk bahasa pemrograman PHP, yang memberikan kemampuan untuk menulis dan membaca file spreadsheet dari format file yang berbeda, seperti Excel (BIFF) .xls, Excel 2007 (OfficeOpenXML) .xlsx, CSV, Libre/OpenOffice Calc .ods, Gnumeric, PDF, HTML. Project ini dibangun di daerah OpenXML standar Microsoft dan PHP.

\subsection{HighCharts}

Highcharts merupakan charting library yang di buat oleh tim Highsoft AS dan di luncurkan pada tahun 2009. Highchart ditulis menggunakan JavaScript murni, menawarkan cara mudah dalam menambahkan grafik yang interaktif untuk website atau aplikasi website.

\subsection{AJAX}

AJAX, singkatan dari "Asynchronous JavaScript and XML", merupakan metode suatu laman web menggunakan JavaScript untuk mengirim dan menerima data dari server tanpa harus menyegarkan (refresh) laman itu. XML adalah sejenis markup language - seperti HTML, yang kerap dipakai untuk mengirimkan data melalui internet. Belakangan ini, JSON ("JavaScript Object Notation") lebih populer dan bisa dibaca secara bawaan (native) - oleh JavaScript. Berikut uraian yang lebih ringkas:

Sebuah contoh perintah AJAX bisa berjalan seperti berikut:

- Client memanggil laman dari server

- Server merespon panggilan dan mengirimkan laman

- Client membuat perintah AJAX ke server dan memanggil lebih banyak data

- Server mengirimkan data tersebut

- Client memutakhirkan laman dengan data tersebut tanpa me-refresh laman. 
- Facebook, Gmail, dan Pinterest adalah contoh situs-situs yang banyak menggunakan AJAX.

Bagian "Asynchronous" merujuk pada fakta bahwa ketika JavaScript menyampaikan panggilan AJAX ke webserver, ia terus berjalan sampai memperoleh respon - ia tidak memblokir dan berhenti saat data sedang diproses oleh server.

\subsection{MySQL}

Tiap database memiliki table-tabel, tiap tabel memiliki field-field. Umumnya informasi tersimpan dalam tabel-tabel yang secara logis merupakan struktur-struktur dimensi terdiri atas baris dan kolom. Field-fieldtersebut dapat berupa data seperti int, real, char, date, time, dan lainnya.Pemakaian dasar SQL adalah sebagai berikut:

1. Mendefinisikan Tabel

CREATE TABLE NAME_TABLE (DEFINISI_TABLE);

2. Menyimpan Data

$\begin{array}{lr}\text { INSERT INTO } & \text { NAME_TABLE } \\ \text { (DAFTAR_FIELD) } & \text { VALUES }\end{array}$

(DAFTAR NILAI);

3. Mengambil Data

SELECT DAFTAR_FIELD FROM

NAMA_TABLE KONDISI;

4. Mengubah Data

UPDATE NAMA_TABLE

DATA_FIELD_LAMA

DATA_FIELD_BARU;

5. Menghapus Data

DELETE FROM NAMA_TABLE KONDISI;

\subsection{FrameworkCodeIgniter}

Framework adalah abstraksi di dalam sebuah perangkat lunak yang menyediakan fungsi yang generic sehingga dapat dirubah oleh kode yang dibuat user sehingga dapat menyediakan perangkat lunak untuk aplikasi tertentu.CodeIgniter merupakan sebuah framework pemrograman web dengan menggunakan bahasa php. Framework ini ditulis dengan menggunakan bahasa php versi 4 dan versi 5 oleh Rick Ellislab yang menjadi CEO Ellislab, Inc. dan dipublikasikan dengan lisensi di bawah Apache/BSD Open Source. Jadi CodeIgniter adalah framework php dan Open Source.

\section{PERANCANGAN SISTEM}

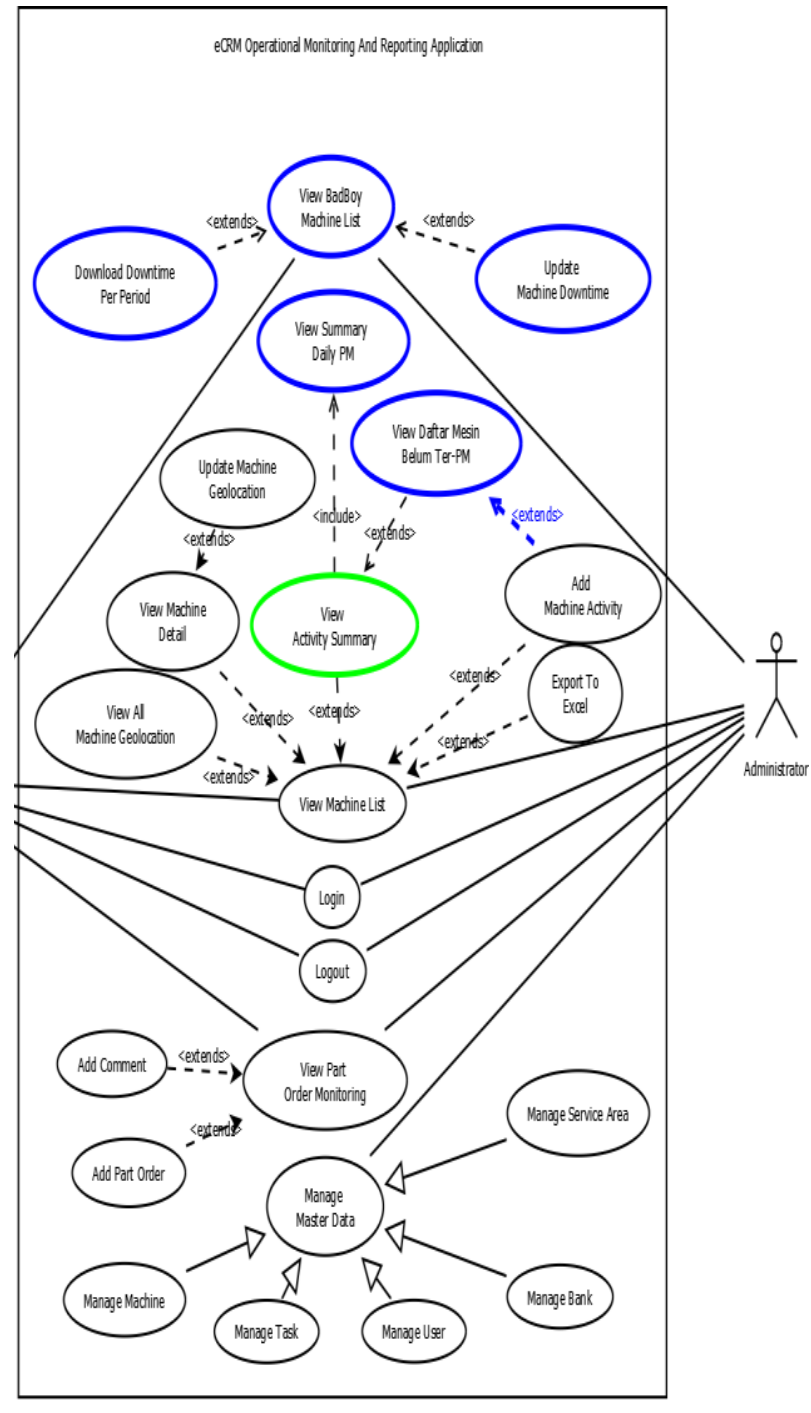

Gambar 1. Usecase Diagram Sistem

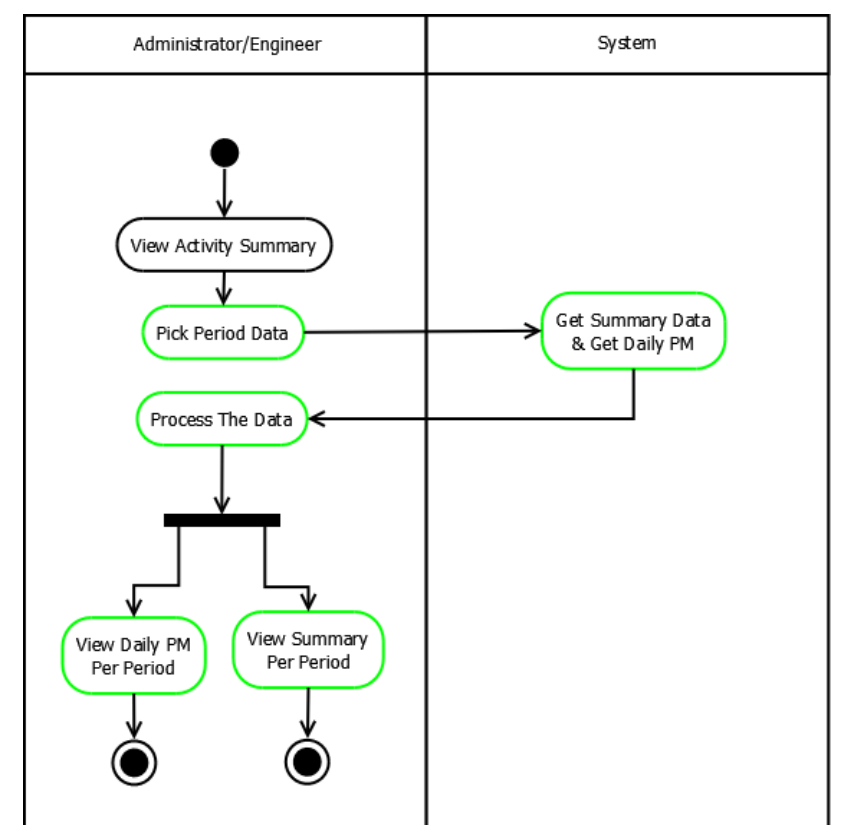

Gambar 2.Activity Diagram View Summary 


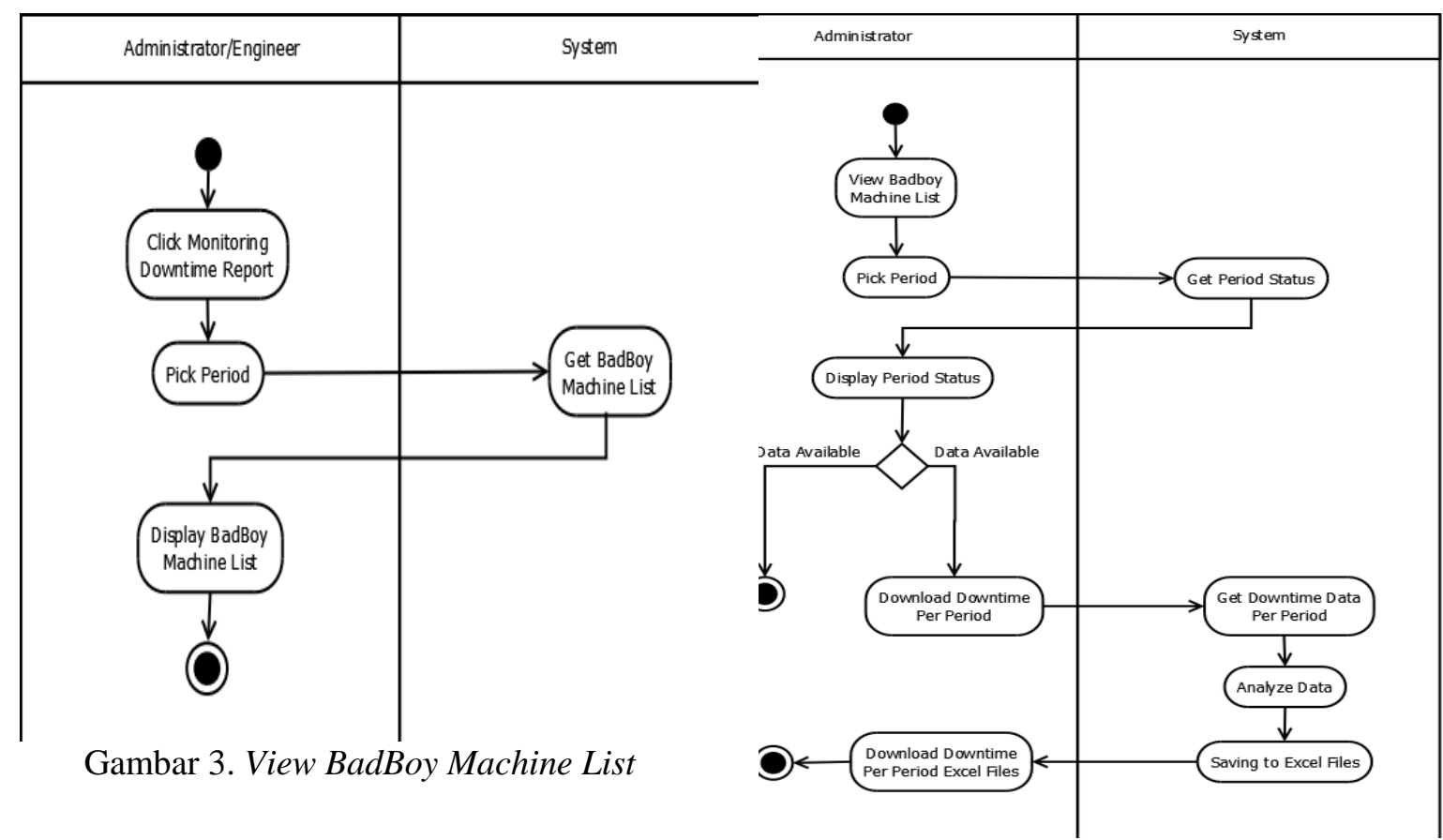

Pada diagram View BadBoy Machine List menampilkan salah satu kegiatan untuk menampilkan daftar mesin yang dikategorikan oleh sistem sebagai badboy.

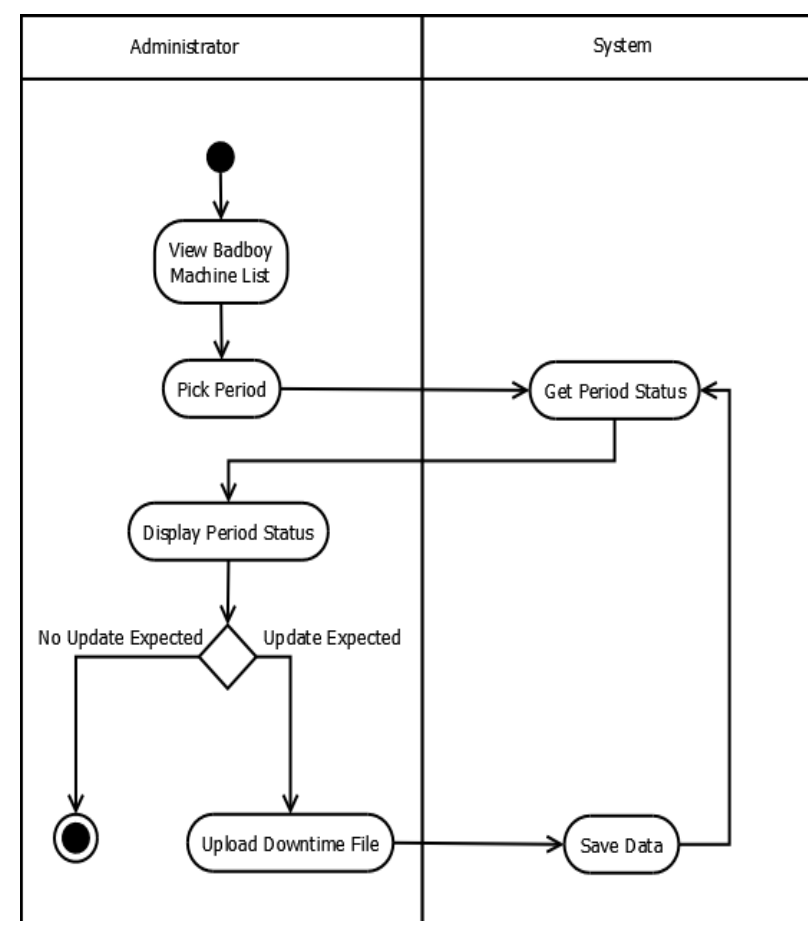

Gambar 4.Activity Diagram Update Machine Downtime

Diagram Update Machine Downtime menampilkan bagaimana kegiatan update data downtime oleh administrator dimana cara meng-update tersebut adalah dengan mengupload file downtime yang diberikan oleh client dan sistem akan membacanya untuk di simpan ke dalam database.

Pada diagram Download Downtime Per Period menampilkan bagaimana kegiatan disaat administrator berniat untuk mengambil / download data downime perperiode dalam bentuk excel. Dimana sepenuhnya di buat oleh sistem menggunakan library yang disediakan oleh PHPExcel.

\section{HASIL DAN PEMBAHASAN}

\section{Tampilan Sistem}

Usecase yang digunakan adalah View Badboy Machine List, Update Downtime Data, dan Download Downtime per Period. Ketiga usecase ini merupakan sebuah satu kesatuan menu baru yaitu Downtime Reporting. Yang pada utamanya adalah View Badboy Machine List yang selanjutnya di extends menjadi Update Downtime Data dan Download Downtime per Period.

Pada gambar 6 menunjukan bagaimana tampilan bentuk sistem. Di dahului dengan memilih periode berapa yang akan di tampilkan, lalu dengan mengklik tombol View, maka akan menampilkan seluruh data berdasarkan periode tersebut. Yang berupa graphic bar berdasarkan servicearea masing masing. Dan tabel yang menunjukan detail data yang di tampilkan. 


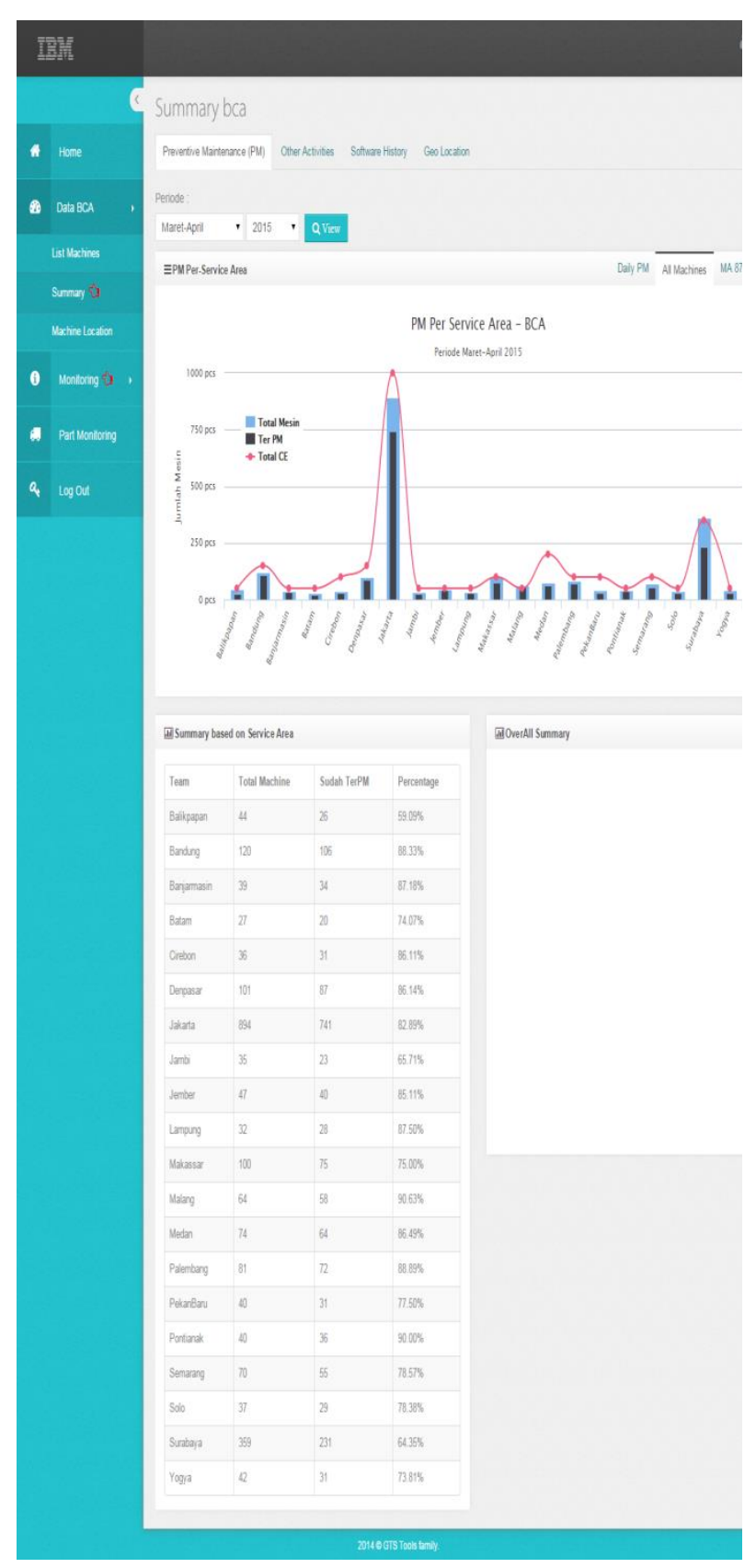

Gambar 6. Halaman summary

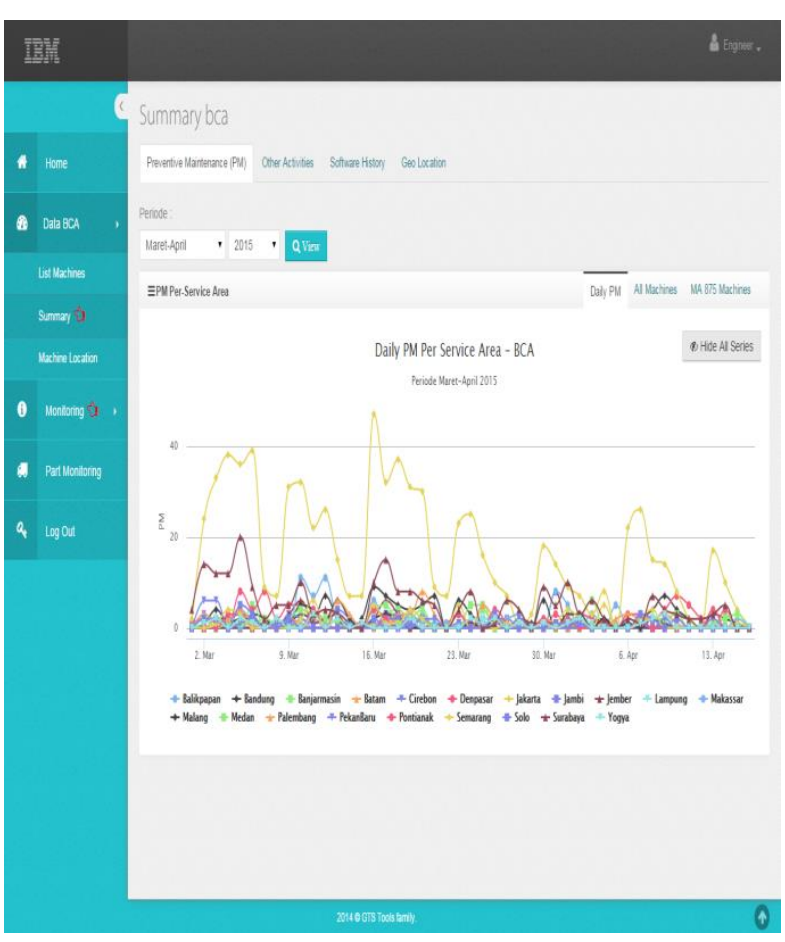

Gambar 7. Halaman Daily PM

Pada gambar 7menampilkan tampilan data Daily PM yang dibagi berdasarkan kategori service area yang ada di Indonesia. Menu ini merupakan pengembangan dari tampilan utama summary dengan memilih tab Daily PM pada menu di atas. Dengan mengarahkan kursor mouse ke line chart akan menunjukan detail data yang ada. Klik ke salah satu kategori akan menyembunyikan data kategori tersebut atau menampilkan data kategori tersebut. Dan denganmengklik tombol pada kanan atas grafik, akan berefek untuk menyembunyikan atau menampilkan seluruh data yang ada.

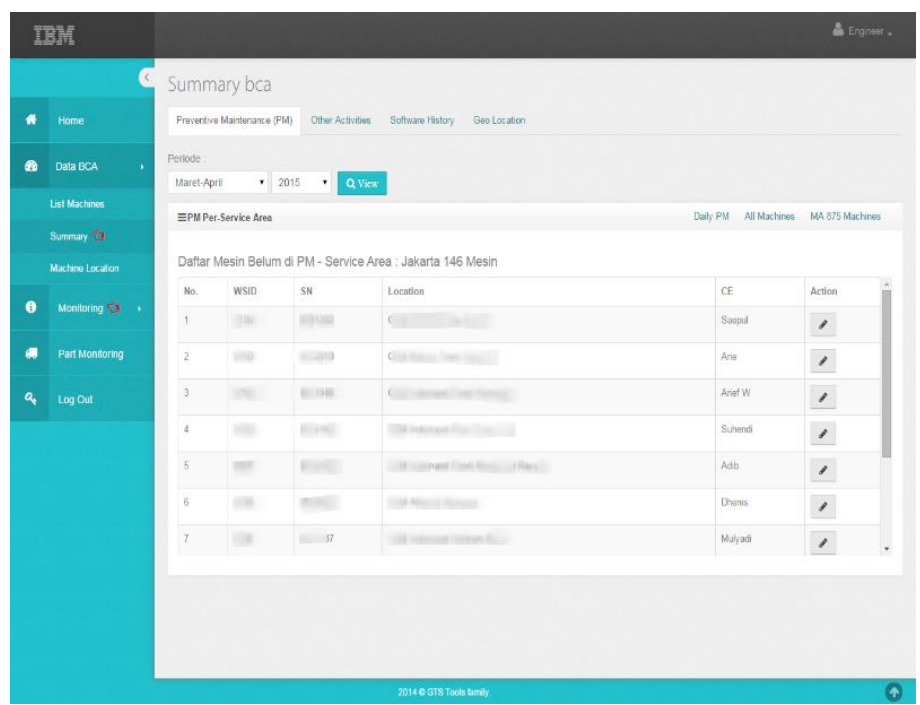

Gambar 8. Halaman daftar mesin belum ter-PM 
Pada gambar 8 memperlihatkan tampilan halaman daftar mesin yang belum ter-PM. Dengan mengklik salah satu bar chart pada halaman view summary, makan akan menampilkan dafar mesin seperti ini. Pada menu ini user dapat melakukan kegiatan seperti pada menu machine list, yaitu add machine activity. Dengan mengklik tombol dengan logo pensil pada sebelah kanan daftar masing masing mesin. Dengan begitu user tidak perlu pindah menu berulang ulang yang dapat memakan waktu lebih lama.

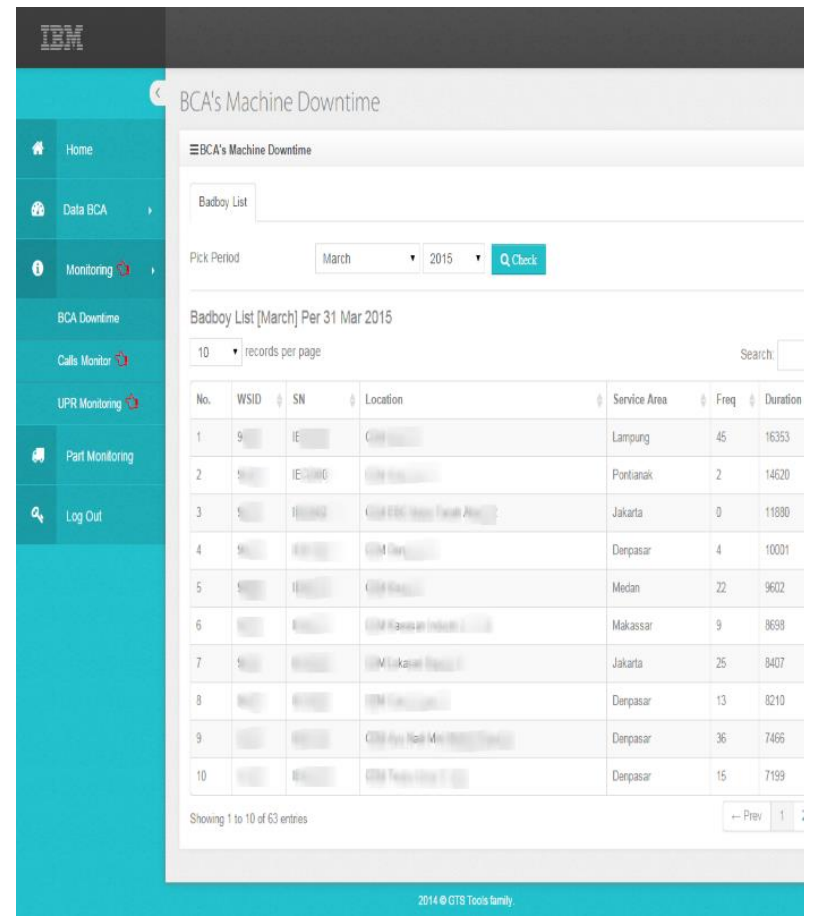

Gambar 9. Halaman Badboy Machine List

Pada gambar 9 menunjukan bagaimana daftar mesin yang di kategorikan sebagai badboy di tampilkan. Dengan memilih periode yang di inginkan untuk ditampilkan, lalu mengklik tombol check, maka sistem akan menampilkan daftar mesin yang hanya di kategorikan badboy.

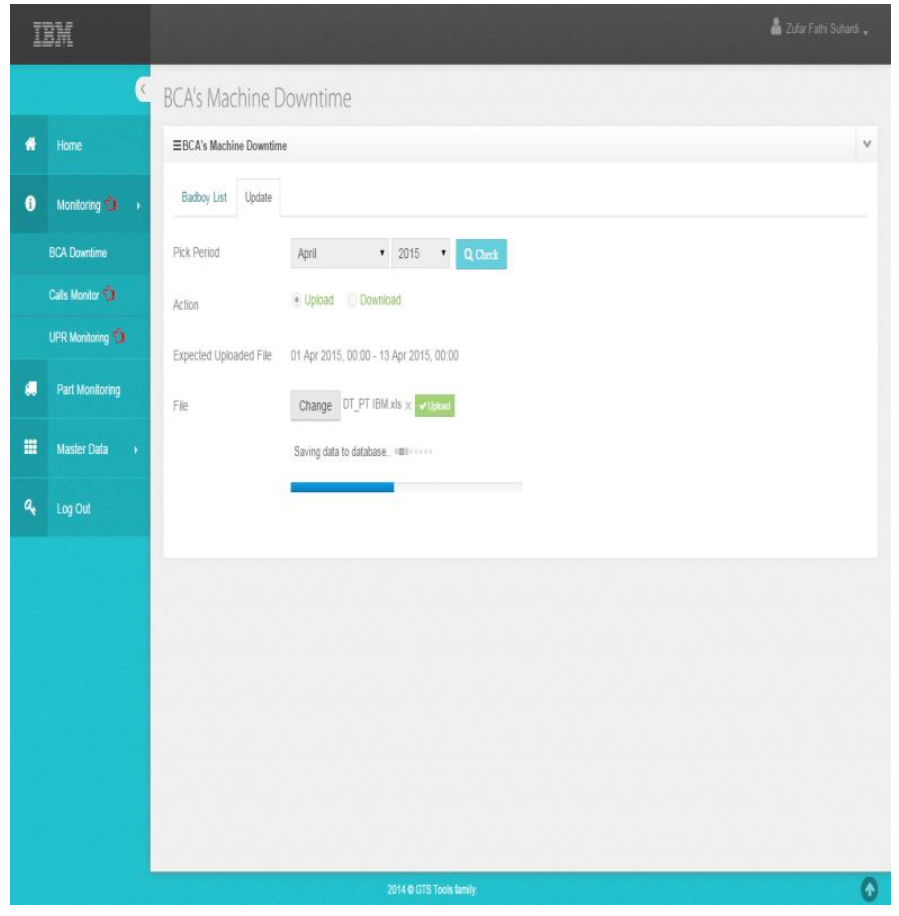

Gambar 10. Form Add Activity

Pada gambar 10 menunjukan bagaimana tampilan menu untuk meng-Update data downtime. Dengan memilih periode yang akan di update, lalu klik tombol check. Dan memilih aksi Upload maka user dapat memilih file yang telah di berikan oleh client untuk di upload ke server lalu server akan menyimpan data mesin yang ada ke dalam database. Pada gambar menampilkan aplikasi sedang memproses file excel menjadi data dan sekaligus menyimpan data tersebut kedalam database.

Pada gambar 11 menampilkan bagaimana tampilan menu Download Downtime. Tidak berbeda dengan menu sebelumnya untuk update. Namun pada saat memilih aksi yang akan di lakukan, user harus memilihDownload untuk dapat menDownload data yang di inginkan. Pada gambar di tampilkan saat aplikasi memproses dan mengubah data menjadi file excel. 


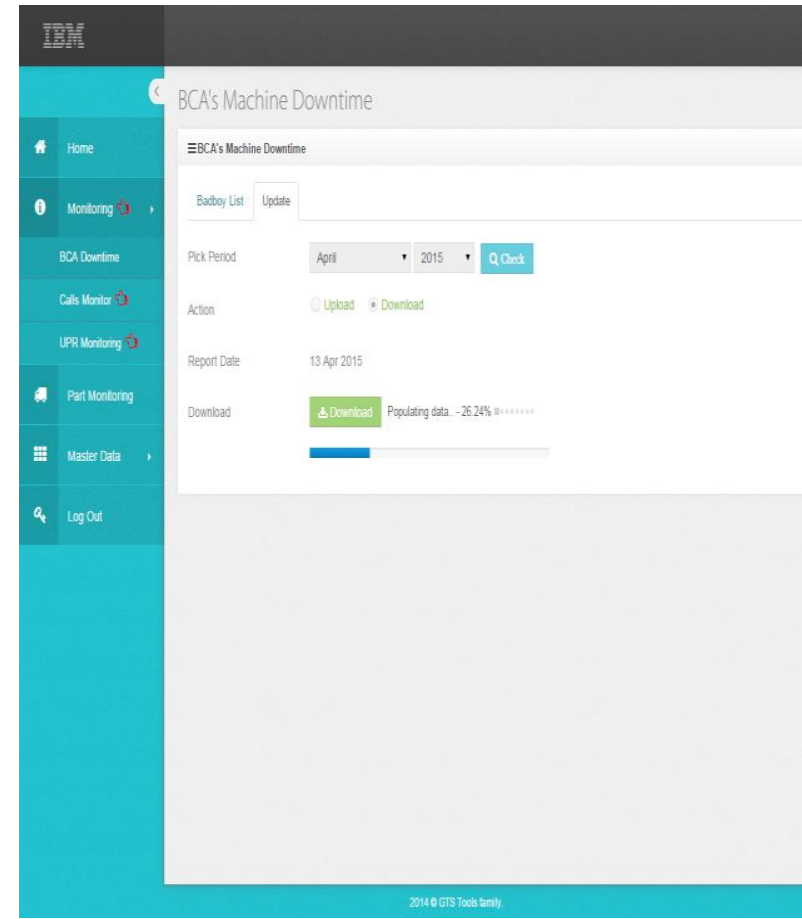

Gambar 11. Halaman Download Downtime

\section{PENUTUP}

1. Membangun fitur downtime reporting sehingga dapat tersimpan data peforma mesin secara terpusat dan memudahkan user dalam memantau status peforma mesin.

2. Membangun user interface baru untuk modul Summary:

a. Dengan menambahkan fitur daily pm dan memberikan tambahan pilihan dalam pemilihan data pada summary pm sehingga lebih banyak informasi yang tersedia dan lebih interaktif.

b. Dengan memberikan fitur add activity, memungkinkan user untuk melakukan aktifitas seperti pada modul manage activity tanpa perlu selalu berpindah halaman sehingga lebih efektif dalam melakukan kegiatan ini.
[1] Dwiartara, Loka, (1st Eds), "Menyelam \& Menaklukan Samudra PHP”, Jakarta. 2013.

[2] Hakim, Lukman,"Membangun Web Berbasis PHP dengan Framework CodeIgniter", Yogyakarta,

Lokomedia.2010.

[3] Basuki, A.P, "Proyek Membangun Website Berbasis PHP dengan Codeigniter",Yogyakarta:

Lokomedia.2014.

[4] Hermawan, J,“Analisa Desain \& Pemrograman Berorientasi Obyek dengan UML dan Visual Basic.NET", Yogyakarta: C.V Andi Offset.

[5]Sunyoto,"AJAX, Membangun Web dengan Teknologi Asyinchronouse JavaScript dan XML. Yogyakarta. Andi Offset.

\section{DAFTAR PUSTAKA}


